\title{
«L'edificio A e la strada settentrionale ». Topoi 10,1 (2000) [2002], Dossier Hatra, pp. 179 - 195, 7 figs.
}

\section{Karin Mosig-Walburg}

\section{(2) OpenEdition \\ 12 Journals}

\section{Édition électronique}

URL : http://journals.openedition.org/abstractairanica/3459

ISSN : 1961-960X

\section{Éditeur :}

CNRS (UMR 7528 Mondes iraniens et indiens), Éditions de l'IFRI

Édition imprimée

Date de publication : 15 mai 2005

ISSN : 0240-8910

\section{Référence électronique}

Karin Mosig-Walburg, « «L'edificio A e la strada settentrionale ». Topoi 10,1 (2000) [2002], Dossier

Hatra, pp. 179 - 195, 7 figs. », Abstracta Iranica [En ligne], Volume 26 | 2005, document 152, mis en ligne le 08 décembre 2005, consulté le 25 septembre 2020. URL : http://journals.openedition.org/

abstractairanica/3459

Ce document a été généré automatiquement le 25 septembre 2020.

Tous droits réservés 
«L'edificio A e la strada settentrionale ». Topoi 10,1 (2000) [2002], Dossier Hatra, pp. 179 - 195, 7 figs.

\author{
Karin Mosig-Walburg
}

1 L'A. traite la question des phases de construction, de la technique et de la chronologie. On a trouvé en plusieurs endroits de l'édifice A des traces d'une occupation postérieure à la prise de la ville par les Sassanides.

INDEX

Thèmes : 3.2.3. Séleucides, Parthes et Sassanides

\title{
AUTEURS
}

KARIN MOSIG-WALBURG

Université de Francfort 